\title{
Respiratory Watch: Development of a provincial system for respiratory syncytial virus surveillance in Nova Scotia, 2005-2008
}

\author{
Assaad Al-Assam PhD ${ }^{1,2,4}$, Joanne M Langley MD MSc $2,3,4$, Shelly Sarwal MD MSc ${ }^{1,2,4,5}$
}

\begin{abstract}
A Al-Assam, JM Langley, S Sarwal. Respiratory Watch: Development of a provincial system for respiratory syncytial virus surveillance in Nova Scotia, 2005-2008. Can J Infect Dis Med Microbiol 2009;20(4):e153-e156.
\end{abstract}

OBJECTIVE: Respiratory syncytial virus (RSV) is the most common cause of severe lower respiratory tract infection in young children and is increasingly recognized as a cause of influenza-like illness in those older than 65 years of age. A surveillance system to provide timely local information about RSV activity in Nova Scotia (NS) is described.

METHODS: A case report form was developed for weekly reporting of all laboratory isolates of RSV at diagnostic laboratories around the province. Laboratories were asked to send the forms by fax each Friday to the Nova Scotia Department of Health Promotion and Protection. Data were entered in Excel (Microsoft, USA) and aggregate results summarized by age, sex, health district and date of laboratory confirmation for 2005 to 2008.

RESULTS: During three winter seasons (2005-2006, 2006-2007 and 2007-2008), there were 207, 350 and 186 isolates of RSV reported in NS, respectively. The average incidences of RSV in NS varied greatly by age, with the highest rates in infants younger than 24 months of age, and approaching 4000 cases per 100,000 population in infants up to five months of age. The duration of the RSV outbreak was approximately five to six months each year, but the month of onset varied. CONCLUSIONS: A RSV surveillance system was successfully established in NS that provides weekly data to the public health system, clinicians and infection control practitioners. The time of onset and severity of the RSV season varied over time. These data can be used to plan anti-RSV passive prophylaxis programs and infection control education, and distinguish RSV outbreaks from other viruses in acute care and long-term care settings.

Key Words: Respiratory syncytial virus; Surveillance

$\mathrm{R}$ espiratory syncytial virus (RSV) is the most common cause of severe lower respiratory tract infection in young children, and is associated with respiratory tract morbidity in the immunocompromised, and in community- and residential-dwelling persons older than 65 years of age (1). During annual winter outbreaks, $50 \%$ to $80 \%$ of infant bronchiolitis requiring hospital admission is due to RSV, with rates approaching 10 admissions per 1000 children in Canada (2). Observational data suggest that admissions for RSV-associated bronchiolitis are increasing over time $(3,4)$.

Although there is no commercially available vaccine against RSV, a passive immunization strategy using an antiRSV monoclonal antibody (palivizumab; Synagis, Abbott Laboratories Ltd) is recommended for certain high-risk children, such as infants younger than 24 months of age with

\author{
Élaboration d'un système provincial de \\ surveillance du virus syncytial respiratoire en \\ Nouvelle-Écosse, 2005-2008
}

\begin{abstract}
OBJECTIF : Le virus syncytial respiratoire (VSR) est la cause la plus fréquente des infections des voies respiratoires inférieures graves chez les jeunes enfants et est de plus en plus reconnu comme facteur étiologique des maladies pseudogrippales chez les personnes de plus de 65 ans. On décrit ici un système de surveillance visant à fournir rapidement des renseignements sur l'activité locale du VSR en Nouvelle-Écosse (N.-É.).

MÉTHODES : Un formulaire de signalement a été conçu pour le suivi hebdomadaire de tous les isolats de VSR confirmés en laboratoire diagnostique dans la province. Les laboratoires ont été invités à retourner les formulaires par télécopieur chaque vendredi à la direction de la promotion et de la protection de la santé de la Nouvelle-Écosse. Les données ont été saisies au moyen du logiciel Excel (Microsoft, États Unis) et les résultats regroupés ont été résumés par âge, sexe, région sanitaire et date de confirmation par les laboratoires, de 2005 à 2008.

RÉSULTATS : Durant les trois saisons hivernales (2005-2006, 2006-2007 et 2007-2008), on a dénombré respectivement 207, 350 et 186 isolats de VSR en N.-É. L'incidence moyenne du VSR en N.-É. a beaucoup varié selon l'âge, les taux les plus élevés ayant été observés chez les nourrissons de moins de 24 mois, avec près de 4000 cas par 100000 de population chez les nourrissons de cinq mois et moins. La durée de l'éclosion de VSR a été d'environ cinq à six mois chaque année, mais le moment du déclenchement a varié.

CONCLUSION : Un système de surveillance du VSR a été mis sur pied avec succès en N.-É. pour fournir des données hebdomadaires au système de santé publique, aux médecins et aux responsables de la lutte aux infections. Le moment du déclenchement de la saison des infections à VSR et leur gravité ont varié dans le temps. Ces données seront utiles pour planifier des programmes de prophylaxie passive et de sensibilisation à la lutte aux infections à VSR et pour distinguer les éclosions d'infections à VSR des éclosions d'autres infections virales dans le contexte des soins aigus et des soins prolongés.
\end{abstract}

chronic lung disease resulting from premature birth, or with hemodynamically significant heart disease (5). Up to $20 \%$ of hospitalized infants with RSV-associated lower respiratory tract infection require admission to the intensive care unit and need respiratory support. Prophylactic use of palivizumab has been shown to reduce the risk of hospitalization associated with RSV infection $(6,7)$. Palivizumab is given monthly for five injections just before and during the RSV season.

We describe the development of a provincial surveillance system developed to provide timely information about RSV.

\section{METHODS}

RSV is not a reportable disease in Canada (8,9). Nova Scotia (NS) participates in FluWatch, Canada's national influenza

${ }^{1}$ Formerly with the Department of Health Promotion and Protection, Government of Nova Scotia; ${ }^{2}$ Departments of Community Health and Epidemiology and ${ }^{3}$ Pediatrics; ${ }^{4}$ Canadian Center for Vaccinology, IWK Health Centre and Dalhousie University; ${ }^{5}$ Department of Health Promotion and Protection, Government of Nova Scotia, Halifax, Nova Scotia

Correspondence: Dr Joanne M Langley, Canadian Center for Vaccinology, IWK Health Centre, 5890 University Avenue, Halifax, Nova Scotia B3K 6R8. Telephone 902-470-8141, fax 902-470-7232, e-mail jmlangle@dal.ca 


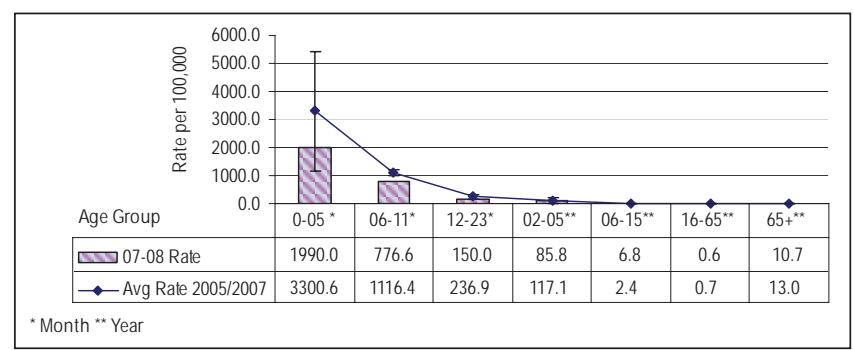

Figure 1) Respiratory syncytial virus isolations by age group, per 100,000 population in Nova Scotia. Avg Average

surveillance system, which collects national data on several indicators of influenza including influenza-like illness presenting to certain sentinel physicians, laboratory-confirmed influenza and institutional outbreaks (10). NS also contributes to the Respiratory Virus Surveillance Detection System of the Public Health Agency of Canada, which summarizes laboratory-confirmed influenza, RSV, parainfluenza and adenovirus (11). However, before 2005, the only laboratory that routinely reported laboratory confirmations of RSV to public health was the Virology Laboratory at the Capital Health District in Halifax.

There are nine district health authorities in NS; a telephone survey of district laboratories was conducted to determine whether RSV testing was done, and whether the laboratory was willing to report RSV on a weekly basis. All six laboratories that were conducting local testing agreed to collaborate. There were no private laboratories that performed RSV testing in operation at the time of the present project. All health districts include rural and urban areas, including the capital health district of Halifax Regional Municipality. The largest urban area is Halifax, which has a population of greater than 300,000.

A one-page case report form was developed for collection of data each week. A minimum number of variables were selected to reduce workload on the laboratories and maintain patient confidentiality. Variables collected included the name of the diagnostic laboratory, and the patient's age and sex. Duplicates were not identified. Laboratories were not required to use a particular testing methodology, and a variety of tests were used including culture, polymerase chain reaction and immunoassay. Laboratories were asked to send the forms by fax each Friday to the Department of Health Promotion and Protection in Halifax. Data were entered on Excel (Microsoft, USA) and aggregate results summarized by age, sex, district health authority and date of laboratory confirmation for each year. Incidence and age specific rates were calculated by using 2001 Census, Statistics Canada.

Weekly Respiratory Watch reports summarizing respiratory virus activity are distributed by e-mail each week to any interested persons including public health units, physicians and infection prevention and control practitioners, and posted on the Web site of the department at http://www.gov.ns.ca/hpp/ ocmoh/flu.htm. When respiratory virus activity settles in late spring, the frequency of distribution of the Respiratory Watch reports decreases to every two weeks.

\section{RESULTS}

During the 2005-2006, 2006-2007 and 2007-2008 seasons there were 207, 350 and 186 cases of RSV reported in NS, respectively. Males were affected $55.6 \%, 49.7 \%$ and $54.3 \%$ of the time during the three seasons, respectively.

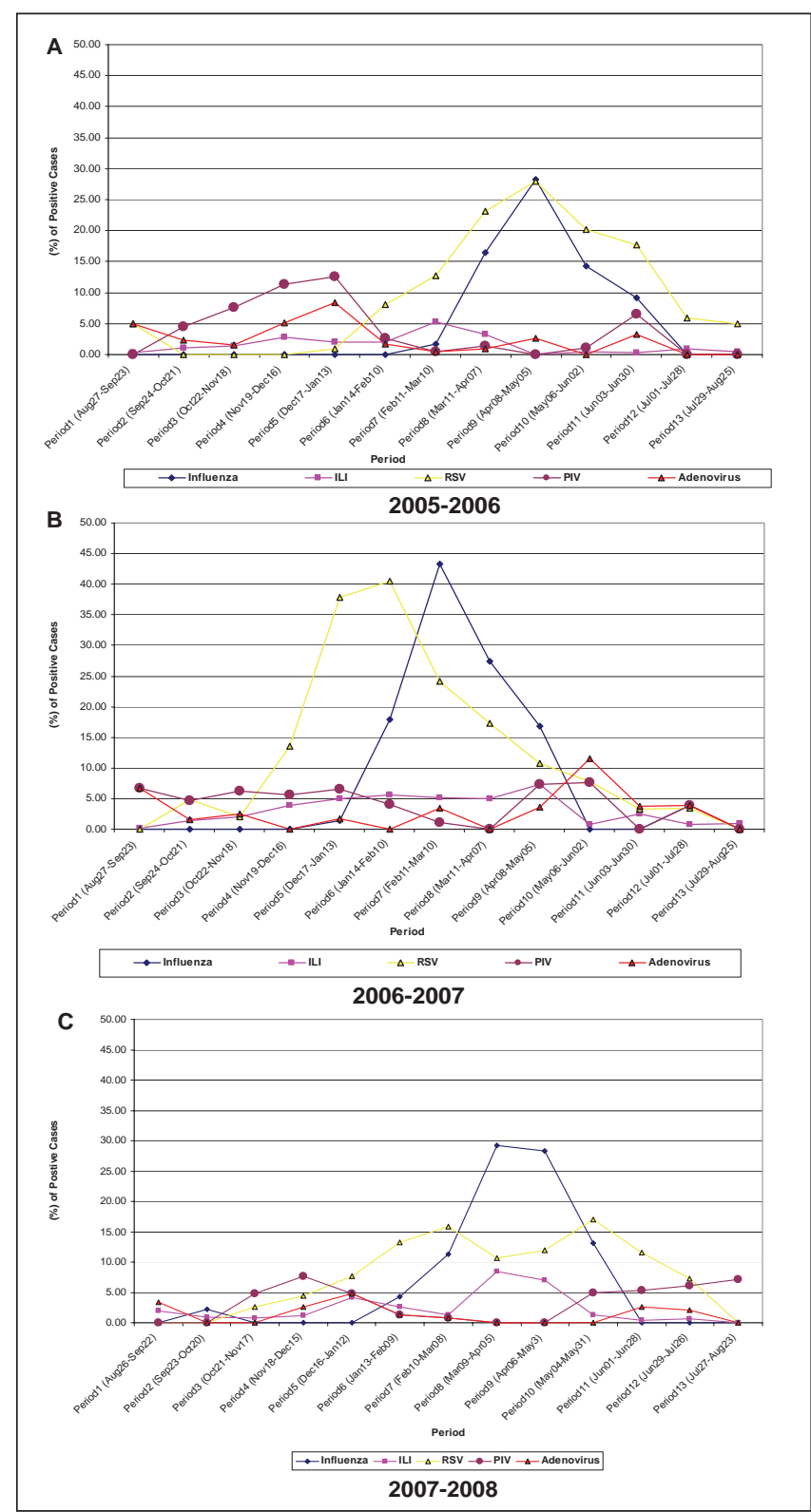

Figure 2) Respiratory diseases activities in Nova Scotia, 2005-2008. A 2005-2006; B 2006-2007; C 2007-2008. ILI Influenza-like illness; PIV Parainfluenza virus; RSV Respiratory syncytial virus

The average incidence of RSV varied greatly by age (Figure 1). The highest incidence of RSV was among children younger than 24 months of age, with infants zero to five months having a rate as high as 3938.8 cases per 100,000 population. The absolute number of RSV identifications in the zero- to five-month-old age group were 35 (2005-2006), 89 (2006-2007) and 31 (2007-2008). Males had higher rates than females. The lowest rate was among those 16 to 65 years of age ( 0.7 cases per 100,000 population). Rates increased in persons older than 65 years of age (12.2 cases per 100,000 population) and were over 12 times higher than in younger adults (Figure 1).

The onset and peak periods of RSV activity varied over time, but the duration of each year's outbreak was similar, lasting five to six months. In 2005-2006, the RSV season started in February, peaked in April and ended in July (Figure 2A). In the 


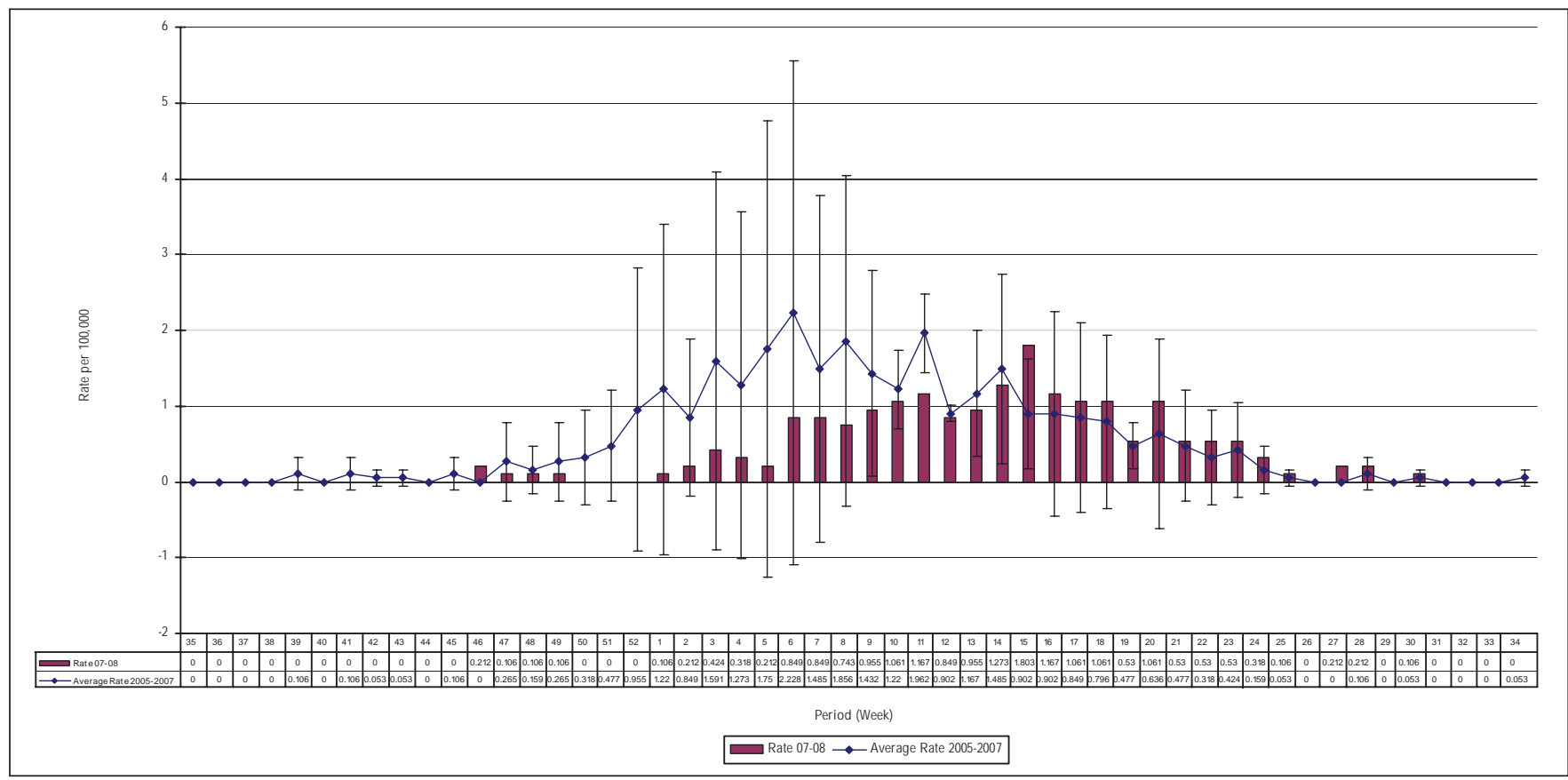

Figure 3) Laboratory-confirmed respiratory syncytial virus illness in 2007-2008, per 100,000 population, compared with activity in 20052007

subsequent season the onset was in December, with a peak in February and ending in late May (Figure 2B). During 20072008 there were two peak periods (February/March) and (May/ June) with the epidemic ending in late June (Figure 2C). The severity of the outbreak, as measured by the overall incidence of infections, also varied over time.

The RSV and influenza seasons were not distinct, with RSV shouldering influenza. Parainfluenza and adenovirus activity did not occur concurrently with RSV and influenza (Figure 2). RSV was identified as the causative agent for $6.5 \%$ of respiratory outbreaks in schools or long-term care facilities over three seasons. The season-to-season variability in timing of the annual epidemic is seen in Figure 3.

\section{DISCUSSION}

RSV is not a reportable illness in Canada, and without efforts by clinicians and the public health community to enhance surveillance, limited information to guide planning of RSV prophylaxis programs will be available. Palivizumab is an expensive intervention, costing at least $\$ 5,000$ per child each season in the first year of life. Knowledge of the highest risk period, in which the prophylaxis is likely to be of benefit, allows clinicians and planners to appropriately use human and material resources required for program delivery. Knowledge of the timing of the annual RSV outbreak can also permit recognition of outbreaks in the community and residential settings, and distinguish illness due to different pathogens (12). This can enhance timely annual infection control education by care providers, including education of families of young children and the elderly, and of health care workers of high-risk children, newborns being discharged into the community, the immunocompromised and those older than 65 years of age.

It is used in our province in the planning process for the provincial palivzumab program.

Our surveillance system has been functioning as a collaboration among multiple partners including microbiology laboratories, public health and clinicians. It is currently a voluntary system and relies on data collected as part of routine care and the FluWatch program. As such, the burden of illness associated with RSV is likely greatly underestimated. In particular, FluWatch is oriented more toward adult than pediatric respiratory infection. Viral respiratory illness in children has a more diverse clinical presentation than in adults in whom the definition of 'influenza-like illness' in FluWatch is a fairly accurate syndrome, especially when influenza is circulating in the community. A more comprehensive system of sentinel physicians, who provide care for children and for elderly persons, looking for different types of respiratory illness in addition to influenza, would provide a more accurate estimate of the burden of illness associated with RSV and other viruses. Other methods of data collection could be explored, including a Web-based system (13) and more proactive engagement of community clinician involvement. More comprehensive case detection would clearly have resource implications.

There are several weaknesses to our study. With only three years of data the sample size is too small to describe local epidemiology, which may well be different than data summarized from a provincial perspective. For example, consistent annual patterns have been found in some countries (14), with year-to-year variation in others $(15,16)$. Longer-term surveillance will remediate this issue and allow integration of annual surveillance data into the provincial planning process (17). As well, the non-nominal nature of our data means duplicate reporting could occur. However, many laboratories reject second specimens from the same patient if a previous positive is on record, so it is unlikely that this occurred in many patients.

ACKNOWLEDGEMENTS: The authors thank Drs Jane MacDonald, Maureen Baikie and Jeffrey Scott who assisted in the development of this program, and the participating district laboratories in Nova Scotia (IWK Health Centre, Capital Health 
District, Yarmouth Regional, Cape Breton Regional, Colchester Regional, and Valley Regional).

This paper was presented in part at the Canadian Public Health Association Conference June 2-5, 2008, Halifax, Nova Scotia, and the 8th Canadian Immunization Conference November 30-December 3, 2008, Toronto, Ontario.

\section{REFERENCES}

1. Falsey AR. Respiratory syncytial virus infection in adults. Semin Respir Crit Care Med 2007;28:171-81.

2. Schanzer DL, Langley JM, Tam TW. Hospitalization attributable to influenza and other viral respiratory illnesses in Canadian children. Pediatr Infect Dis J 2006;25:795-800.

3. Shay DK, Holman RC, Newman RD, Liu LL, Stout JW, Anderson LJ. Bronchiolitis-associated hospitalizations among US children, 19801996. JAMA 1999;282:1440-6.

4. Langley JM, LeBlanc JC, Smith B, Wang EE. Increasing incidence of hospitalization for bronchiolitis among Canadian children, 19802000. J Infect Dis 2003;188:1764-7.

5. National Advisory Committee on Immunization. Canadian Immunization Guide, 7th edn. Ottawa: Minister of Public Works and Government Services Canada, 2006.

6. Palivizumab, a humanized respiratory syncytial virus monoclonal antibody, reduces hospitalization from respiratory syncytial virus infection in high-risk infants. The IMpact-RSV Study Group. Pediatrics 1998;102:531-7.

7. Feltes TF, Cabalka AK, Meissner HC, et al. Palivizumab prophylaxis reduces hospitalization due to respiratory syncytial virus in young children with hemodynamically significant congenital heart disease. J Pediatr 2003;143:532-40.

8. Case definitions for diseases under national surveillance. Canada Communicable Diseases Report - Releve des maladies transmissibles au Canada 2000;26:1-122.

9. National Notifiable Diseases. Public Health Agency of Canada, 2008. <http://dsol-smed.phac-aspc.gc.ca/dsol-smed/ndis/list_e. html>. (Version current at November 18, 2008).

10. Reyes F, Macey JF, Aziz S, et al. Influenza in Canada: 2005-2006 season. Can Commun Dis Rep 2007;33:21-41.

11. Respiratory Virus Detections/Isolations in Canada. Public Health Agency of Canada, 2008. <http://www.phac-aspc.gc.ca/bid-bmi/dsddsm/rvdi-divr/index-eng.php>. (Version current at November 18, 2008)

12. Fox JD. Respiratory virus surveillance and outbreak investigation. J Clin Virol 2007;40 Suppl 1:S24-30.

13. Hammond L, Papadopoulos S, Johnson CF, MaWhinney S, Nelson B, Todd JK. Use of an Internet-based community surveillance network to predict seasonal communicable disease morbidity. Pediatrics 2002;109:414-8.

14. Goddard NL, Cooke MC, Gupta RK, Nguyen-Van-Tam JS. Timing of monoclonal antibody for seasonal RSV prophylaxis in the United Kingdom. Epidemiol Infect 2007;135:159-62.

15. Terletskaia-Ladwig E, Enders G, Schalasta G, Enders M. Defining the timing of respiratory syncytial virus (RSV) outbreaks: An epidemiological study. BMC Infect Dis 2005;5:20.

16. Panozzo CA, Fowlkes AL, Anderson LJ. Variation in timing of respiratory syncytial virus outbreaks: Lessons from national surveillance. Pediatr Infect Dis J 2007;26:S41-5.

17. Warren A, Langley JM, Thomas W, Scott J. Optimizing the delivery and use of a new monoclonal antibody in children with congenital heart disease: A successful provincial respiratory syncytial virus prophylaxis program. Can J Cardiol 2007;23:463-6. 


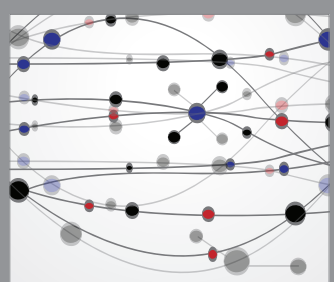

The Scientific World Journal
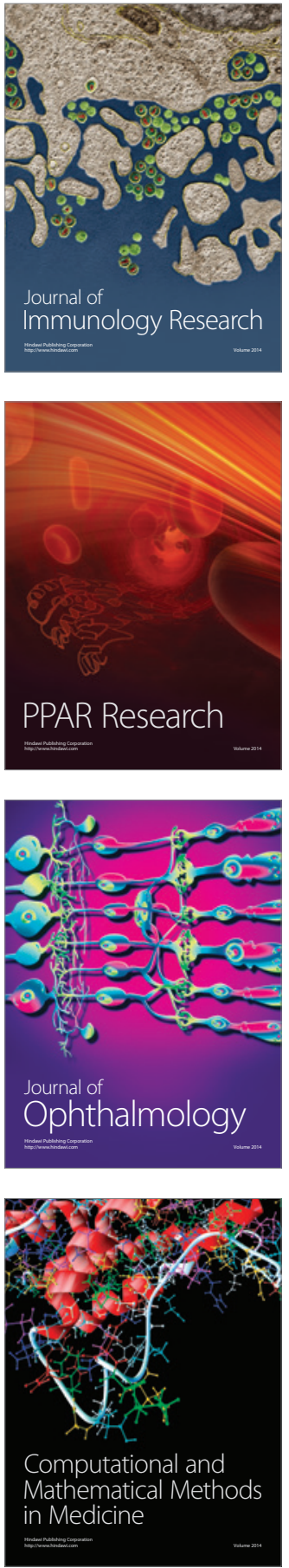

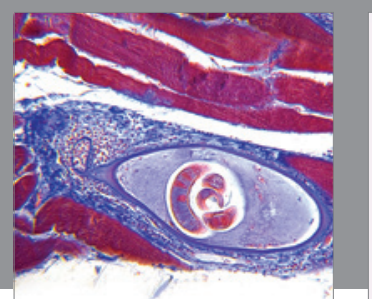

Gastroenterology Research and Practice

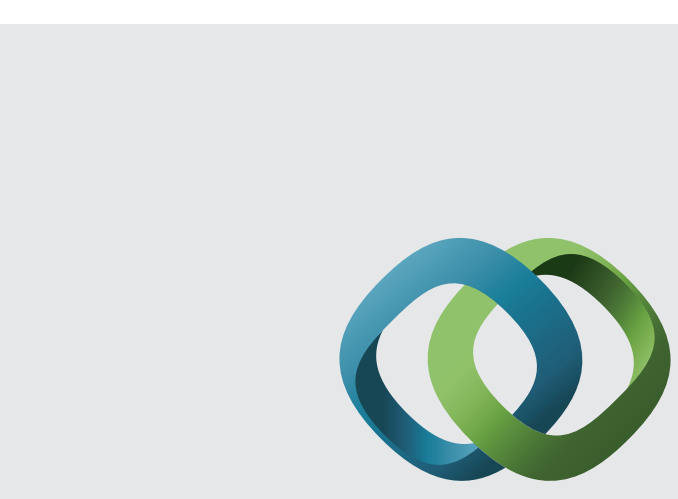

\section{Hindawi}

Submit your manuscripts at

http://www.hindawi.com
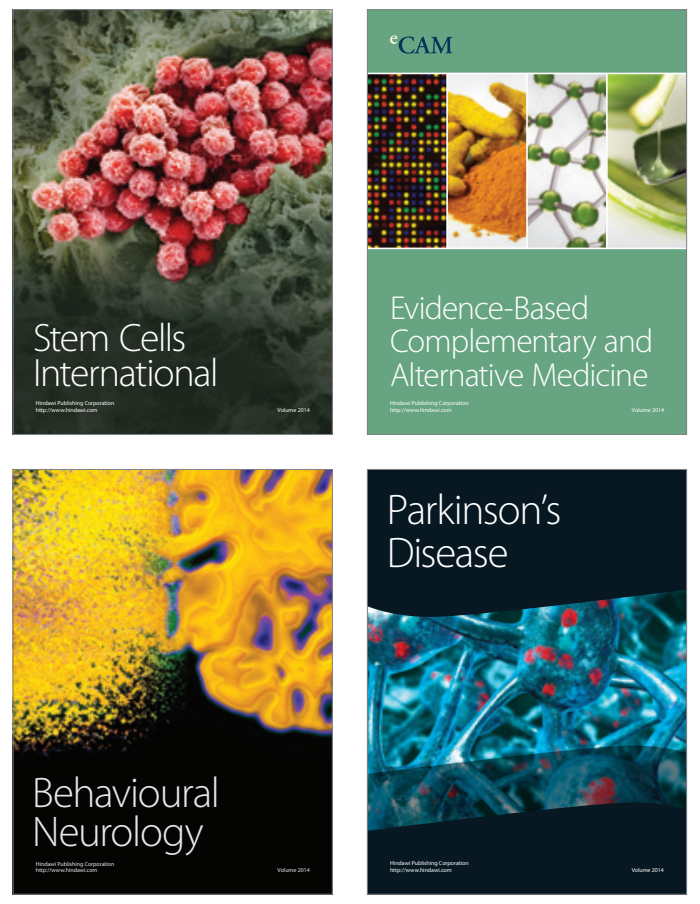
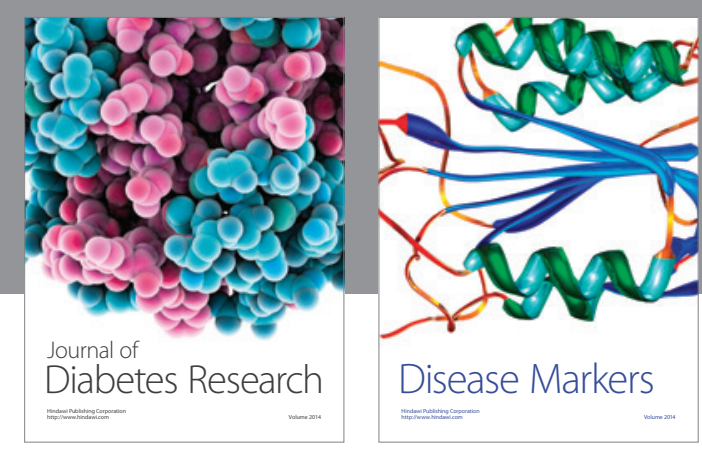

Disease Markers
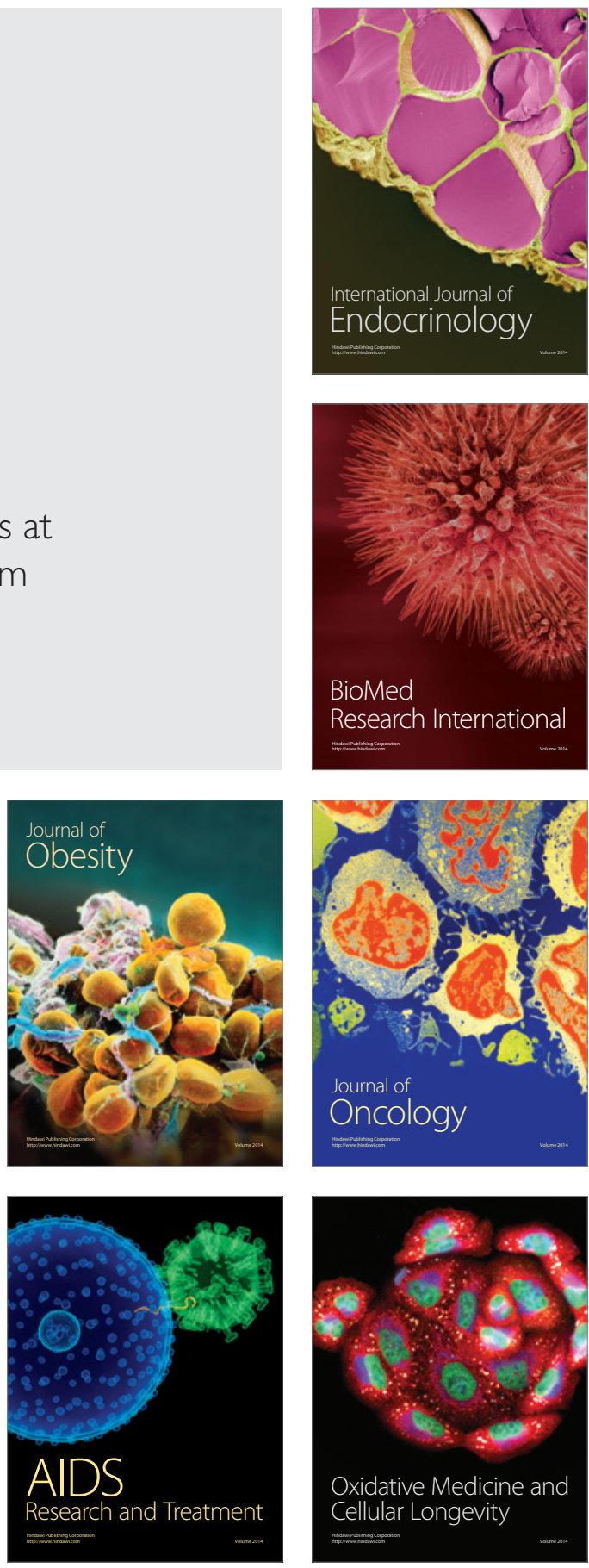